\title{
LOW BLOOD GLUCOSE LEVELS AND OTHER COM- PLICATIONS DURING GROWTH HORMONE SUPPLEMENTATION IN SEPSIS
}

\author{
Joel Faintuch, Renata B. A. Leme, Maria Emilia L. F. Cruz, Angela \\ M. B. Lima, Daniel Giannella Neto and Joaquim J.Gama-Rodrigues
}

RHCFAP/2978

\begin{abstract}
FAINTUCH, J. et al. - Low blood glucose levels and other complications during growth hormone supplementation in sepsis. Rev. Hosp. Clín. Fac. Med. S. Paulo 54 (4): 135 - 138, 1999.
\end{abstract}

SUMMARY: Blood glucose levels in the high normal range or even moderate hyperglycemia is the expected profile in septic postoperative patients receiving high-calorie enteral alimentation. The addition of growth hormone as an anabolic agent should additionally reinforce this tendency. In a cancer patient undergoing partial gastrectomy with lymphadenectomy and suffering from postoperative subphrenic abscess and prolonged sepsis, tube feeding $(38.3 \mathrm{kcal} / \mathrm{kg} / \mathrm{day})$ and growth hormone $(0.17 \mathrm{IU} / \mathrm{kg} /$ day) were simultaneously administered for 25 days. Blood glucose levels were in the lower limits of the normal range before growth hormone introduction, and continued with a similar tendency during most of the therapeutic period. Two additional complications, namely heart arrest and peripheral edema, were documented during the same period. It is concluded that sepsis was the most likely mechanism for low glucose values, and that high-calorie enteral diet and growth hormone supplementation did not prevent that result. It is uncertain whether heart arrest was due to the drug, but its association with peripheral edema is well documented in clinical series.

DESCRIPTORS: Growth Hormone. Enteral Nutrition. Hypoglycemia. Sepsis. Peripheral Edema.

Malnourished cancer patients in the perioperative period are at high risk for septic complications ${ }^{3}$. Nutritional support, preferably via the enteral route ${ }^{12}$, is an accepted modality for accelerating recovery and inhibiting infectious complications in this and other critical situations, and an enhanced result might be produced by supplementation with recombinant human growth hormone $(\mathrm{GH})^{22 .} \quad$ It is true that in cancer populations, some studies with $\mathrm{GH}$ failed to demonstrate appreciable benefits $^{15}$. However, in our own experience $^{8,}$ as well as in that of others ${ }^{19}$, encouraging responses without significant side effects have been observed even in these circumstances.

The present report deals with the unusual findings of blood glucose concentrations in an elderly, malnourished, surgical, and septic cancer patient managed with high-calorie enteral feeding and adjunctive $\mathrm{GH}$ administration.

\section{CASE REPORT}

A 67-year-old male was admitted with the diagnosis of gastric cancer of the antrum. Curative subtotal gastrectomy was performed, but a left subphrenic abscess that did not yield to conservative measures appeared in the late postoperative period. After 33 days, another laparotomy was indicated, and the abscess was debrided and drained. The patient progressed with a septic course, malnutrition, dependent edema, pleural effusions, and respiratory failure. Mechanical ventilation was required for a total of 39 days, and hemodynamic instability demanding vasoactive drugs occurred during seven days.

Throughout the second postoperative hospitalization, cultures from the

From the Nutrition Group, Department of Gastroenterology, "Hospital das Clínicas", São Paulo, Brazil. wound site and various drains and catheters revealed Escherichia coli, Pseudomonas aeruginosa, Enterobacter cloacae, Enterococcus faecalis and Staphyloccocus aureus, which were treated according to antibiotic sensitivity tests. White blood cell counts were permanently elevated during the hospital stay at levels of $10,400-39,000$ cells $/ \mathrm{mm}^{3}$.

Nutritional findings at admission: Height $1.68 \mathrm{~m}$, weight $47.0 \mathrm{~kg}$, body mass index $16.7 \mathrm{~kg} / \mathrm{m}^{2}$, serum albu$\min 30 \mathrm{~g} / \mathrm{L}$, hemoglobin concentration $12.3 \mathrm{~g} / 100 \mathrm{~mL}$.

Dietetic management: Immediately after the reoperation, severe ileus contraindicated use of the gastrointestinal tract. Parenteral alimentation was thus introduced, in the proportion of $1800 \mathrm{kcal} /$ day $(38.3 \mathrm{kcal} / \mathrm{kg} /$ day $)$. By the ninth postoperative day, tube feeding was phased in, aiming at the same energy intake and employing a polymeric commercial diet. 
Anthropometric and biochemical variables fluctuated during the hospitalization period, but without a clear trend (Table 1). The only exception was during intermittent episodes of dependent edema, as well as pleural effusion, during which body weight increased and serum albumin diminished to as little as $23 \mathrm{~g} / \mathrm{L}$, requiring the utilization of albumin replacement, diuretics, and pleural catheter drainage. Sepsis was a feature of the entire hospital stay, and so was persistent muscle weakness, preventing early discontinuation of artificial ventilation (Table 1).

Growth hormone program: On the 16th day after subphrenic abscess operation, GH therapy was introduced as an adjunct to the enteral diet, to stimulate protein anabolism ${ }^{22}$, increase muscle strength to enable the patient to recover vigorous thorax expansion6, and enhance the immune response ${ }^{11}$. The clinical status of the patient was not considered incompatible with such medication, since he didn't suffer from systemic or intracranial hypertension, was not diabetic, displayed no extrarespiratory organ failures, and had no clinical evidence of active cancer at that moment.

Given the fact that in subjects undergoing long-term ventilatory support, average duration of GH therapy is in the range of 5-6 weeks6, a preliminary plan of a 4-week supplementation was defined at $8 \mathrm{IU} /$ day $(0.17$ $\mathrm{IU} / \mathrm{kg} /$ day). Actual duration of the program was 25 days. Nutritional findings remained stable during this period. Septic manifestations did not disappear. However, muscle strength increased, and the patient was successfully weaned from the ventilator by the end of this time.

Several unexpected episodes occurred simultaneously with GH use. The most serious was a heart arrest of undetermined cause, which occurred on the seventh day of prescription of the drug and which was successfully reversed. The patient developed superficial coma and muscle deficits in the limbs, but fully recovered in the ensuing two weeks.

Peripheral edema of hands and feet was the second noteworthy event. Previously mentioned disturbances with dependent edema and pleural effusion did not recur during GH therapy, but by the third week of treatment, fluid accumulation in the distal part of the extremities was evident. Shortly thereafter, the hormone was discontinued, but the patient continued to display the uncommon feature of large hands giving the impression of boxing gloves, as well as comparably swollen feet, which contrasted with the otherwise thin and malnourished limbs. The edema was soft, painless, and easily depressed, and it disappeared within approximately three weeks.

During the postoperative course of the patient, blood glucose levels maintained a strange pattern that started before the introduction of $\mathrm{GH}$ and continued thereafter, requiring constant monitoring and occasional therapeutic intervention. Despite the fact that there were two predisposing conditions for hyperglycemia, namely septic catabolism and hypercaloric diet, to which the introduction of $\mathrm{GH}$ further contributed, and despite the elderly condition of the patient, glycemic measurements close to the lowest limit of normal occurred on various occasions. True hypoglycemia (below $3.5 \mathrm{mmol} / \mathrm{L}$ ) was clinically suspected but never confirmed, although the complication may have been masked by frequent administrations of intravenous hypertonic glucose, started prophylactically whenever glucose levels below $4.5 \mathrm{mmol} / \mathrm{L}$ were found.

As a matter of fact, modest hyperglycemia did occur as well during a 3day period shortly after the heart arrest, as well as on a few other occasions. Still, the majority of the laboratory tests indicated normal or lownormal readings (Table 2 ).

\section{DISCUSSION}

Depressed blood glucose determinations should not be surprising dur- ing advanced malnutrition, but surgery and sepsis classically modify this perspective, due to hormone and cytokine imbalance. The addition of GH-therapy is deemed nutritionally advantageous within this critical setting, but could further damage glucose regulation ${ }^{4,16,17}$.

Hyperglycemia is definitely considered a potentially limiting factor for prescribing $\mathrm{GH}$ to elderly or diabetic populations ${ }^{1}$.

Rare pulmonary, pancreatic, or neuroendocrine cancers manufacture hormones or peptides with glucoselowering properties, but such a finding is extremely unusual for gastric adenocarcinoma $^{5}$. Moreover, this patient maintained normal preoperative glucose concentrations, underwent radical extirpation of his disease, and had no evidence of tumor recurrence by the time glucose fluctuations were recognized.

Extensive clinical experience with GH in adults has never revealed hypoglycemia $^{1-3,5}$, and even direct administration of human recombinant IGF-1 to critically ill patients failed to elicit such an abnormality ${ }^{20}$. It should be noted that glucose decreases were diagnosed before the introduction of the hormone in the present case.

It would seem a paradox to incriminate sepsis itself for the biochemical aberration, but severe hypoglycemia and even hypoglycemic seizures may on occasion be triggered by bacterial and parasitic processes $7,10,18$. Why a condition so intimately associated with glucose intolerance should be a possible cause for the opposite effect is still incompletely understood. Impaired gluconeogenesis has been suspected in this context ${ }^{18}$, but interleukin-6 could also be involved with this phenomenon $^{10 .}$ In rats, circulating endotoxin induces hypoglycemia, among other effects, and GH may enhance some of the metabolic responses ${ }^{16}$.

In the current study, cytokine or endotoxin measurements were not available, and gluconeogenesis studies were not performed. Nevertheless septic metabolic changes could be the 
Table 1 - General laboratory determinations

\begin{tabular}{l|c|c|c|c}
\hline Variable / Date Pre- & GH started Heart arrest GH discontinue \\
\hline Serum albumin $(\mathrm{g} / \mathrm{L})$ & operative & 17 th P.O. & 23 rd P.O & 42nd P.O. \\
Hemoglobin $(\mathrm{g} / \mathrm{dL})$ & 30 & 28 & 27 & 34 \\
White blood cells (/mm3 ) & 12.3 & 1.0 & 10.9 & 13.0 \\
\hline
\end{tabular}

Obs.: P.O.: Post-operative day

Table 2: Blood glucose concentrations during the GH supplementation period

\begin{tabular}{|c|c|c|c|c|}
\hline Day & $8 \mathrm{AM}$ & $2 \mathrm{PM}$ & $8 \mathrm{PM}$ & $2 \mathrm{AM}$ \\
\hline 13th PO & 6.7 & 4.5 & 5.5 & 7.5 \\
\hline 14 th “ & 3.9 & 6.4 & 8.1 & \\
\hline 15 th $“$ & 5.5 & 6.4 & 6.2 & 7.1 \\
\hline 16th “ & 7.0 & 7.8 & 6.3 & 6.3 \\
\hline 17th “ GH started & 5.0 & 7.6 & 7.6 & 7.6 \\
\hline 18th “ & 5.1 & 6.0 & 6.9 & \\
\hline 19th “ & 6.4 & 7.8 & 5.5 & 6.3 \\
\hline 20th “ & 11.9 & 7.5 & 8.3 & \\
\hline 21 st $“$ & 8.8 & 6.4 & 9.5 & 7.6 \\
\hline 22nd “ & 9.1 & 12.5 & 0.1 & \\
\hline 23rd "Heart arrest & 11.9 & 7.1 & 4.8 & 5.9 \\
\hline 24th “ & 6.8 & 6.0 & 6.9 & \\
\hline 25 th $“$ & 9.4 & 10.0 & 10.6 & 10.0 \\
\hline 26th “ & 10.2 & 10.2 & 8.9 & 9.2 \\
\hline 27 th $“$ & 10.2 & 10.2 & 9.2 & .2 \\
\hline 28th “ & 5.0 & 8.9 & 8.9 & 6.2 \\
\hline 29th “ & 6.0 & 7.9 & 8.5 & 8.2 \\
\hline 30th “ & 4.9 & 6.8 & 7.0 & 6.7 \\
\hline 31 st “ & 6.2 & 7.8 & 7.3 & 6.7 \\
\hline 32nd “ & 7.1 & 3.9 & 8.0 & 6.2 \\
\hline $33 \mathrm{rd}$ “ & 6.9 & 9.7 & 6.9 & 11.3 \\
\hline 34 th “ & 7.5 & 7.0 & 8.8 & \\
\hline 35 th $“$ & 8.3 & 9.2 & 7.8 & 7.8 \\
\hline 36th “ & 8.3 & 8.7 & 8.1 & \\
\hline 37 th “ & 6.6 & 7.9 & 11.8 & 9.0 \\
\hline 38th “ & 6.0 & 6.1 & 5.6 & \\
\hline 39th “ & 7.4 & 7.7 & 10.0 & 9.7 \\
\hline 40th “ & 7.6 & 7.0 & 6.4 & \\
\hline 41 st “ & 7.8 & 8.3 & 10.6 & \\
\hline 42nd “ GH stopped & 6.8 & 8.5 & 8.8 & \\
\hline 43rd “ & 7.0 & 6.7 & 8.6 & \\
\hline 44th “ & 6.2 & 8.5 & 5.6 & \\
\hline 45th “ & 6.2 & 7.1 & 6.2 & \\
\hline
\end{tabular}

Obs.: Normal glucose range 3.5 - $9.0 \mathrm{mmol} / \mathrm{L}$;

Hypertonic glucose administered IV whenever glycemia $<4.5 \mathrm{mmol} / \mathrm{L}$;

P.O. : Postoperative day;

predominant explanation for the findings. Hypoglycemia was certainly demonstrated days ahead of GH use, in a phase of very severe disease. Nevertheless, it is interesting to notice that the anabolic agent did not prevent its continuation, and perhaps even contributed toward its maintenance for some time (Table 2).

As mentioned before, the eventful course of GH-supplementation in this experience included two other surprises. Heart arrest is not currently accepted as a GH-dependent complication $1,2,5,22$, and many other circumstances could have been responsible for this accident. Severe electrolyte imbalance, hypoxia, or heart arrhythmia were ruled out in this mishap, but the subject was nevertheless a frail malnourished elderly man with septic complications and undergoing artificial ventilation. In our preliminary results with this agent, no cardiac abnormalities were detected ${ }^{8}$, and it is believed that GH may be beneficial to heart function in long-term programs $^{13 .}$. Therefore, it is not certain that GH played a role in this problem.

As regards peripheral edema, it has been associated with $\mathrm{GH}$ administration for a long time ${ }^{1,2}$, but we were still surprised by its relatively rapid onset and anatomical severity. Yet this was a relatively benign complication with moderate functional impairment, which was mostly a cosmetic inconvenience and did not require any specific treatment. As already indicated, it was essentially reabsorbed by the third week.

Perhaps the overarching question in the entire episode reported here is the indication and tolerance of $\mathrm{GH}$ pharmacotherapy during critical illness. There is sufficient evidence in the literature that sepsis and organ failures do not preclude a positive result from such supplementa-

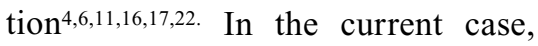
recovery of food ingestion and spontaneous breathing clearly coincided with GH administration. At the same time, it is suspected that elevated morbidity and mortality may also be a consequence in critical patients, in some yet insufficiently defined settings ${ }^{21}$. Whether this depends on the ability of GH to potentiate the inflammatory response to circulating endotoxin $^{9}$, or to interfere with other endogenous mediators, is presently unknown and clearly requires further investigation.

In conclusion, this was a case of growth hormone supplementation in a critically ill, septic postoperative patient that was followed by a depressed glycemic pattern, plus two additional complications, namely heart arrest, and peripheral edema. A strong association with the drug can only be made regarding peripheral edema, but it may be speculated that the context of high GH concentrations in a seriously ill subject could have had deleterious impact on the other reactions as well. 
FAINTUCH, J. e col. - Baixos níveis de glicemia e outras complicações durante suplementação de hormônio do crescimento na sepse. Rev. Hosp. Clin. Fac. Med. S. Paulo 54 (4): 135 - 138, 1999.

RESUMO: O perfil glicêmico esperado em pacientes pós-operatórios sépticos recebendo nutrição enteral de elevado teor calórico é de valores sanguíneos no limite superior do normal ou mesmo hiperglicemia moderada.A adição de hormônio do crescimento (GH) como agente anabólico deveria reforçar ainda mais esta tendência.Num paciente com câncer submetido a gastrectomia parcial e linfadenectomia, que se complicou no pós operatório com abscesso subfrênico e sepse prolongada, administrou-se conjuntamente dieta de sonda $(38,3 \mathrm{kcal} / \mathrm{kg} / \mathrm{dia})$ e $\mathrm{GH}(0,17$ $\mathrm{UI} / \mathrm{kg} / \mathrm{dia}$ ).Antes da introdução de GH as taxas glicêmicas situavam-se nos limites inferiores do normal, e esta tendência persistiu durante a maior parte do período terapêutico.Duas complicações adicionais, nominalmente parada cardíaca e edema periférico, foram documentadas nesta mesma etapa.Conclui-se que a sepse é o mais provável mecanismo de redução da glicemia neste caso, e que o emprego de dieta enteral e de $\mathrm{GH}$ não conseguiu prevenir tal efeito.É questionável se a parada cardíaca foi devida ao suplemento hormonal, mas o edema periférico é um secundarismo bem conhecido deste agente em estudos clínicos.

DESCRITORES: Hormônio do crescimento. Nutrição enteral. Hipoglicemia. Sepse. Edema periférico.

\section{REFERENCES}

1. BLETHEN S L, ALLEN D B \& GRAVES D - Safety of recombinant deoxyribonucleic acid-derived growth hormone: The National Cooperative Growth Study Experience. J Clin Endocrinol Metab 1996; 81:1704-1710.

2. CUNEO R C, JUDD S \& WALLACE J D - The Australian Multicenter Trial of growth hormone (GH) treatment in GH-deficient adults. J Clin Endocrinol Metab 1998; 83:107-116.

3. DALY J M, REDMOND H P \& GALLAGHER H Perioperative nutrition in cancer patients. JPEN 1992 16(Suppl 6):100S-105S.

4. GATZEN C, SCHELTINGA $M \quad R$ \& KIMBROUGH $T$ D Growth hormone attenuates the abnormal distribution of body water in critically ill surgical patients. Surgery 1992; 112:181-187.

5. HOFF A O \& VASSILOPOLOU S R - The role of glucagon administration in the diagnosis and treatment of patients with tumour hypoglycemia. Cancer 1998, 82:1585-1592.

6. KNOX J B, WILMORE D W \& DEMLING R H - Use of growth hormone for postoperative respiratory failure. Am J Surg 1996; 171:576-580

7. KOCHAR D K \& KUMAWAT B L - Cerebral malaria or Plasmodium falciparum malaria with hypoglycaemia. Lancet 1996; 347:1549-1550.

8. LEME R B A, FAINTUCH J, CRUZ M E L S et al. - Shortterm growth hormone supplementation in high-risk surgical cancer patients. Intens Care Med 1998; 24(Suppl 1):S52.

9. LIAO W, RUDLING $M$ \& ANGELIN B - Contrasting effects of growth hormone and insulin-like growth factor-I on the biological activities of endotoxin int he rat. Endocrinology 1997; 138:289-295.

10. MILLER $\mathrm{S} \mathrm{I}$, WALLACE $\mathrm{R} \mathrm{J} \mathrm{Jr}$ \& MUSHER D M Hypoglycemia as a manifestation of sepsis. Am J Med 1980; 68:649- 654 .

11. SAITO H, INOUE $\mathrm{T}$ \& FUKATSU $\mathrm{K}$ - Growth hormone and the immune response to bacterial infection. Horm Res 1996; 45:50-54.
12. SHIKORA S A \& OGAWA A M - Enteral nutrition and the critically ill. Postgrad Med J 1996; 72:395-402.

13. SILVERMAN B L \& FRIEDLANDER J R - Is growth hormone good for the heart? J Pediatr 1997; 131(1 Pt 2):S70-S74.

14. STRASSMANN G, MASUI $Y$ \& CHIZZANTE R - The role of interleukin-6 in lipopolysaccharide-induced weight loss, hypoglycemia, and fibrinogen production in vivo. Cytokine 1993; 5:285-290.

15. TAYEK J A \& BRASEL J A - Failure of anabolism in malnourished cancer patients receiving growth hormone: A clinical research center study. J Clin Endocrinol Metab 1995; 80:2082-2087.

16. VAN DEN BERGHE G, ZEGHER F \& LAUWERS P Growth hormone secretion in critical illness: effect of dopamine. $\mathbf{J}$ Clin Endocrinol Metab 1994; 79:1141-1146.

17. VAN DEN BERGHE G, ZEGHER F \& VELDHUIS J D The somatotropic axis in critical illness: effect of continuous growth hormone (GH)-releasing hormone and GH-releasing peptide-2 infusion. J Clin Endocrinol Metab 1997; 82:590-599.

18. WILMORE D W - Impaired gluconeogenesis in extensively injured patients with Gram-negative bacteremia. Am J Clin Nutr 1977; 30:1355-1356.

19. WOLF R F, PEARLSTONE D B \& NEWMAN E - Growth hormone and insulin reverse net whole body and skeletal muscle protein catabolism in cancer patients. Ann Surg 1992; 216:280-288.

20. YARWOOD G D, ROSS R J \& MEDBAK S - Administration of human recombinant insulin-like growth factor-I in critically ill patients. Crit Care Med 1997; 25:1352-1361.

21. ZIEGLER T R - Anabolic agents in nutritional support. In: Clinical Congress Program Book, 22 ${ }^{\text {nd }}$, A.S.P.E.N. Lake Buena Vista, FL, USA, 1998. p 117-124.

22. ZIEGLER $\mathrm{T} R$, YOUNG L S \& FERSARI-BALIVIERA E Use of human growth hormone combined with nutritional support in a critical care unit. JPEN 1990; 14:574-581.

Received for publication on the 17/06/99 